\title{
Thermal energy in Brazil, production and use
}

The human being has become mechanical and unable to supply his or her individual and collective needs through subsistent processes; one would need mechanized means for a large-scale production. The energy production enabled the success and dynamics of the process in the industrial revolution, between the 18 th and 19 th centuries. With the various options for energy production (coal, water, wind, etc), comes the challenge of environmental awareness in measuring the demand for natural raw materials. The main objective of the article is to analyse information about the operation of thermoelectric plants and the use of products and byproducts, such as waste and other important aspects. These aspects include the understanding of thermoelectric energy production processes and its advantages and disadvantages, evaluation of the applications of residues and analysis of the cost-benefit of its acquisition, along with the examination of demand for the types of energy used in Brazil. As a regional reference point in Santa Catarina -Brazil - the Jorge Lacerda Complex was the starting point for this study. The data collected and gauged from this work came exclusively from bibliographical research of students and guidance from third-year teachers, from São José School, city of Itajaí SC. Here they concluded that biomass, as a renewable source in energy generation is already part of the Brazilian electric matrix representing $8.2 \%$. This value is more than twice the amount used worldwide, but it still symbolizes only a complementary source, which concretely results in less harmful waste production. Thermoelectric energy, although not clean, is a less polluting option - compared to other non-renewable ones - and contains technologies that reduce environmental impacts. Examples include the reuse of water, filters at the top of the chimneys to reduce the emission of pollutants, and the use of ashes for cement production. Thus, this article sought to cohesively structure the production of thermoelectric energy, making it clear how the process and impacts on the social environment occur. Information can transform realities, through research, the future can be transformed.

Keywords: Thermoelectric energy; Electricity; Natural resources; Waste.

\section{Energia térmica no Brasil, produção e utilização}

O ser humano se tornou mecânico e incapaz de suprir sua necessidade individual e coletiva através de processos subsistentes, necessita de meios mecanizados para uma produção em larga escala. A produção energética possibilitou o sucesso e a dinâmica do processo na revolução industrial, entre os séculos XVIII e XIX. Com as diversas opções de produção energética (carvão, água, eólica, outras), vem o desafio da conscientização ambiental em dosar a demanda da matéria-prima natural. $\mathrm{O}$ artigo tem como objetivo principal analisar informações sobre o funcionamento das termelétricas e o uso dos produtos e subprodutos, como os resíduos, outros aspectos importantes como a compreensão dos processos de produção de energia termelétrica; avaliação das vantagens e desvantagens de sua utilização avaliação das aplicações dos seus resíduos; análise do custo-benefício de sua aquisição e o exame da demanda dos tipos de energia usadas no Brasil, como ponto de referência regional em Santa Catarina - Brasil - partindo da visita ao Complexo Jorge Lacerda sendo o ponto inicial para este estudo. Os dados coletados e aferidos desse trabalho partiram exclusivamente de pesquisas bibliográficas dos alunos e orientação dos docentes do 3 o ano, da Unidade Escolar Colégio São José município de Itajaí -SC, onde puderam concluir que biomassa como fonte renovável na geração de energia já faz parte da matriz elétrica brasileira representando $8,2 \%$. Este valor equivale mais que o dobro utilizado mundialmente, porém ainda simboliza apenas uma fonte complementar, que de forma concreta acarreta menor produção de resíduos nocivos. A energia termelétrica, apesar de não ser totalmente limpa, é uma opção menos poluente - comparada com outras não renováveis - e contém tecnologias que diminuem os impactos ambientais, exemplos são a reutilização da água, filtros no topo das chaminés, que reduzem a emissão de poluentes e a utilização das cinzas para a produção de cimento. Destarte, este artigo buscou estruturar de forma coesa a produção de energia termelétrica, deixando claro como ocorre o processo e os impactos no meio social.

Palavras-chave: Energia termoelétrica; Energia elétrica; Recursos naturais; Resíduos.

\section{Topic: Desenvolvimento, Sustentabilidade e Meio Ambiente}

Reviewed anonymously in the process of blind peer.
Received: 09/03/2021 Approved: 21/05/2021
Andriele Egídio (iD

Universidade do Vale do Itajaí, Brasil http://lattes.cnpq.br/3096448627791051 http://orcid.org/0000-0002-5858-4606 andrieleegidio18@gmail.com

Giulia Dalmolin Vieira (iD)

Universidade do Vale do Itajaí, Brasil http://lattes.cnpq.br/7091672118141497 http://orcid.org/0000-0002-3945-4849 giuliadalmolin2210@gmail.com

Paulo Henrique Santos (10)

Universidade do Vale do Itajaí, Brasil http://lattes.cnpq.br/5454170480475253

http://orcid.org/0000-0002-3979-662X

santosph14@yahoo.com.br

\author{
Francini Binotto Missuiura (iD) \\ Universidade de Passo Fundo, Brasil \\ http://lattes.cnpq.br/1530239586453372 \\ http://orcid.org/0000-0002-3108-8071 \\ fbmissiura@gmail.com \\ Lethicia Mann Machado (iD \\ Universidade do Vale do Itajaí, Brasil \\ http://lattes.cnpq.br/0375782108779897 \\ http://orcid.org/0000-0003-4127-6698 \\ lethi-m@hotmail.com \\ Bibiana Scaratti Moreira (in) \\ Universidade do Vale do Itajaí, Brasi \\ http://lattes.cnpq.br/7495975638699120 \\ http://orcid.org/0000-0003-2234-1802 \\ bibianasm2011@gmail.com
}

Referencing this:

EGIDIO, A.; VIEIRA, G. D.; SANTOS, P. H.; MISSIURA, F. B.; MACHADO, L. M.; MOREIRA, B. S.. Thermal energy in Brazil, production and use. Nature and Conservation, v.14, n.2, p.111-119, 2021. DOI:

http://doi.org/10.6008/CBPC2318-2881.2021.002.0011 


\section{INTRODUCTION}

The human is constantly evolving, one of the great evolutions was the discovery of electrical energy by Tales of Miletus, when rubbing an amber to a piece of sheepskin, observed that pieces of straw and wood fragments began to be attracted just by the amber. Years later, other sources of energy that could be renewable, such as solar energy, and non-renewable, such as thermal power plants were discovered. Thermoelectric plants produce energy through heat, as they are associated with high temperatures, being call thermal energy, figure 1. Benjamin Thompson and James Prescott was the pioneers in the study of thermodynamics area. The energy it is formed because of the movement - kinetic energy - of molecules and particles. The more the molecules move, the greater the release of heat and then more thermal energy will be formed.

For introducing the theme - thermoelectric plants - during the elaboration of this study, the third year classes of high school at São José School Institution, on Itajaí-SC - Brazil, had the opportunity to visit the Jorge Lacerda Thermoelectric Complex (CTJL) Figure 2, located at Avenue Paulo Santos Mello, 555 - Centro, on Capivari De Baixo, in the state of Santa Catarina, Brazil. That Complex it's an integral part of the electric energy production grid of Engie Brasil Energia. CTJL it's considered the largest coal-fired thermal complex in South America.

In Brazil, Engie Brasil Energia (EBE) is the pioneer in energy production, with 56 plants spread across the country, and is considered the largest private energy producer. The complex located in Santa Catarina, where the visitation happened, has thermoelectric, wind and solar energy sources, however its major focus is the generation of electrical energy through heat.

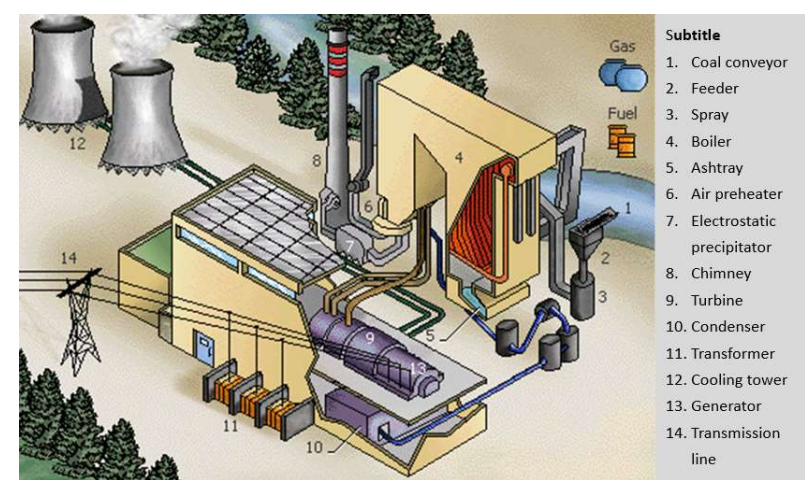

Figure 1: Jorge Lacerda Thermoelectric Complex, Capivari De Baixo -SC - Brazil.

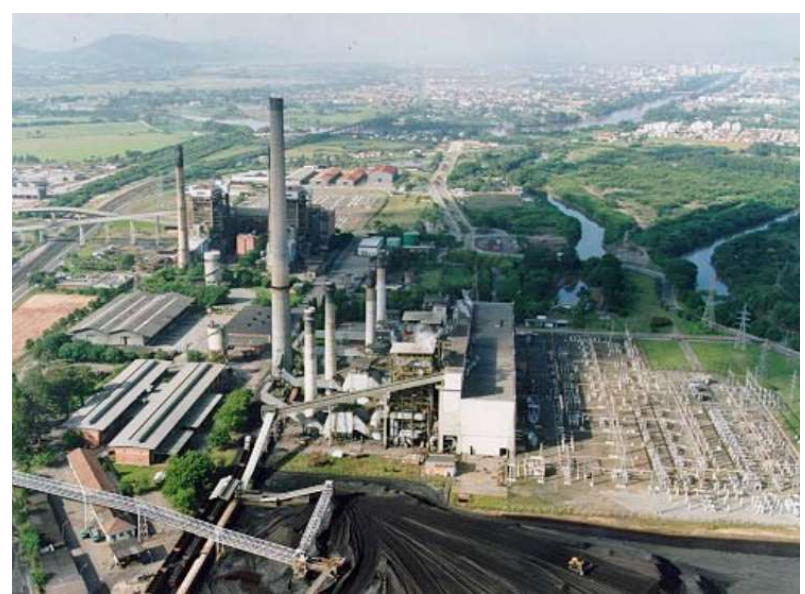

Figure 2: Jorge Lacerda Thermoelectric Complex, Capivari De Baixo -SC - Brazil.

With three thermoelectric plants, the company values the greater conservation of the environment, and in this way two of these plants are newer and contain closed circuits, that is, the steam undergoes condensation in the condenser located in the bottom part of the turbines and saves $95 \%$ of water, always using the same flow. The oldest plant, on the other hand, induces the river that cuts near the plant to demineralization processes before reaching the boilers.

Thus, the article's main objective is to analyse information about the operation of the thermoelectric 
plant and the purpose of its product and by-products, as waste. The understanding of the thermoelectric energy production processes was used as a basis; evaluation of the advantages and damages of this use; evaluation of the applications of this residues; analysis of the cost-benefit of its acquisition and the examination of the demand for the types of energy used in Brazil. Using as a reference point the deepening of thermal energies, focusing on thermoelectric plants and their functions, benefits and harms, using technological means and even visiting the Jorge Lacerda Complex as the starting point for this study.

\section{THEORETICAL REVIEW}

During the evolutionary process of humanity, the human became a mechanic, unable to supply his individual necessities through subsistent processes, needs mechanized means for a large-scale production. As an example of this reality, the First Industrial Revolution, between the 18th and 19th centuries, can be cited, with the greater use of steam machines, namely, energy obtained through the burning of coal. This thermoelectric energy has long research and deepening processes, because its use requires greater awareness of the environment. The process is based on the transformation of energy, and it proceeds from kinetic energy to electrical energy, which can be distributed.

For example, the process used by the Engie Brasil Energia business network, where the visit occurred, approach the mineral coal from Criciúma, which after being ground is taken to the boilers, structures that have networks composed of tubes where the circulation of demineralized water occurs, making it impossible for energy to circulate, preventing electrical shorts. With the heating of the boiler, the water becomes steam, which in the turbine generates kinetic energy and, in the generator, it is transformed into electrical energy.

With alternation between raw materials, being always between fossil fuels (mineral coal, oil and natural gas), the base remains with the same process ideal. On the other hand, political issues are also necessary for greater understanding. Thermoelectric plants started production with the use of mineral coal as a raw material; from the carbonization process of woody organic matter, it was and still is largely responsible for social (contamination of the population and removal of them for the implementation of open pit mines) and environmental (emission of polluting gases) (DRUMM et al., 2014).

However, after the Second Industrial Revolution, great world powers created interests in oil as an active source of thermal energy. Also, because of organic matter, the form of extraction and the high concentration in the Middle East were problematic, which generated serious crises, known as "Oil Shocks", causing notable inflations. In addition to political problems, offshore extraction platforms (at sea) can also cause leaks, devastating oceans and influencing marine fauna, due to their formula composed of hydrocarbons and because it is an oil (CORREIA et al., 2015). Its composition also demonstrates a great polluting capacity in the emission of gases, being responsible for the pollution coming from worldwide automobiles (DRUMM et al., 2014).

With extraction related to oil, natural gas is classified as one of the least polluting fossil fuels, but the emission of gases still remains. Greater attention was paid to it after the "Treaty of La Paz" (1999), which established the construction of the Brazil-Bolivia Gas Pipeline, and is currently the main source of this raw 
material.

However, even with environmental pollution and irresponsibility, fossil fuels remain the raw material for these locations, as they are the sources with the highest thermal capacity, and thermal energy has a large generating capacity. In addition, as detailed during the visitation, "clean" or renewable sources, also known as complementary, have a higher cost and require extensive research.

Brazil uses $56.5 \%$ of non - renewable resources and the world uses $86.0 \%$, this energy matrix is more efficient than the global, figure $3 \mathrm{~A}$. This characteristic is important, since the country emits smaller amounts of greenhouse gases. Regarding the use of renewable sources for electricity generation, Brazil uses $82.0 \%$ of this source, while the world uses only $24.0 \%$, the difference can be explained by the use of energy from the hydroelectric matrix, figure 3B.

Another issue that makes it difficult to use is the distribution of energy, since, according to the National Interconnected System (SIN), responsible for the interconnection of electricity networks, in partnership with the National Electric System Operator (ONS), the production of electricity must match your consumption, establishing an equivalent connection. However, as there is no fixed raw material, complementary energies can deregulate the system because they are not continuous.
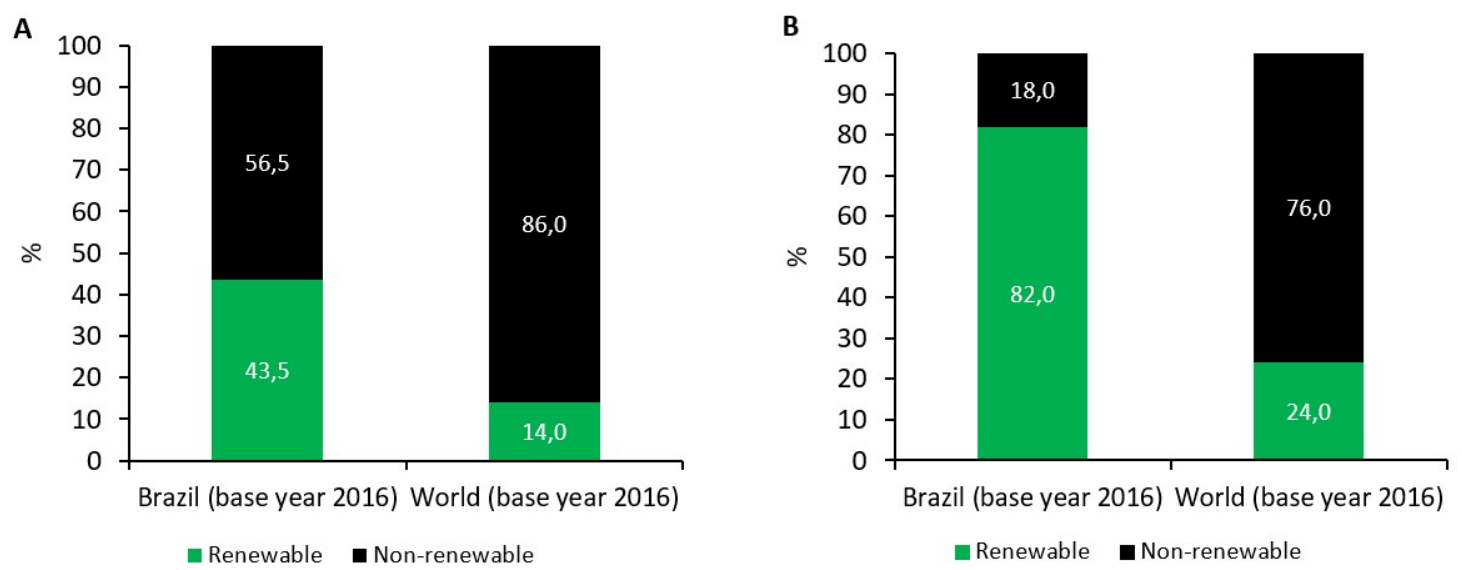

Figure: $3 A$ represents the power consumption of renewable and non - renewable sources in Brazil and in the world. $3 \mathrm{~B}$, represents the use of renewable and non-renewable sources for energy generation in Brazil and worldwide.

Thus, a process initiated by the burning of fossil fuels has undergone evolutions in search of environmental improvements. As a result, even large energy generating companies are required to have a certain responsibility in this matter. For example, Engie Brasil Energia sends ash generated by burning coal to the cement industries, eliminating the residues and, in its most recent construction, the height of the chimneys has increased, reducing the environmental impact, in addition to creating parks for preservation.

Furthermore, the concern with environmental preservation in conjunction with the search for the use of profitable means in each population location causes emerging countries to modify their electrical matrix in a sustainable manner. As shown in table 1, Brazil has a facility for producing energy through hydroelectric systems, reflecting its affluent in union with relevant purposes for these facilities (BRAZIL, 2007). However, the same does not occur worldwide, Table 1, which brings a relevant contrast with the Brazilian electrical matrix (BRAZIL, 2017). While Brazil uses $4.1 \%$ of coal as thermoelectric fossil fuel, the 
second National Energy Balance (BEN), the world the consuming at the rate of $38.3 \%$ according to the International Energy Agency (IEA), Table 1.

Table 1: National and International electrical matrix.

\begin{tabular}{|l|l|l|}
\hline Energy & \% Brazil - 2017 & \% Word - 2016 \\
\hline Hydraulic & 65.2 & 16.6 \\
\hline Natural gas & 10.5 & 23.1 \\
\hline Biomass & 8.2 & 2.3 \\
\hline Solar and Wind & 6.9 & 5.6 \\
\hline Coal & 4.1 & 38.3 \\
\hline Nuclear & 2.6 & 10.4 \\
\hline Oil and Derivatives & 2.5 & 3.7 \\
\hline
\end{tabular}

This change occurs due to the ease in building thermoelectric plants, because even with production costs, the locations are simpler and do not need to be studied as much; besides the fact that some renewable energies depend on weather conditional and the relief of a certain region. In this way, a world with great governmental differences and recurrent problems of an evolutionary process is formed. Therefore, in addition to the flat observation of global society as a whole affected by the irresponsible devastation of the population, it is the most diverse realities that form this set. From socioeconomic concepts to issues of urbanization and the natural landscape of each location must be analysed. The focus remains the same: safe and sustainable development without further delays.

\section{METHODOLOGY}

Bibliographic research was carried out in relation to the concept of thermoelectric plants, establishing a comparison between benefits and harms. Identified which products come from the generation of electric energy through the thermoelectric process and how they can be reused as raw material for other industries. Cost-benefit analysis and demand for thermal energy for the Brazilian population, as it requires a greater amount of resources and maintenance. Study and analysis of other energy sources, by various means.

\section{RESULTS AND DISCUSSION}

What is clear after a certain basis of the process of obtaining energy through thermoelectric plants and the comparison of energy matrices is that fossil fuels are not the best way to be followed. In addition to the environmental damage caused, the source does not guarantee the best form of profit for the Brazilian territory. Consequently, perspectives must be highlighted: first, the economic question. Brazil, dependent on mineral coal as the most profitable source of thermal energy, has deposits spread across the south and southeast, especially Santa Catarina. However, the ore extracted from the Brazilian territory has a quality that varies from poor to average due to its geological formation, which results in a coal with low caloric power and a large amount of ash. Thus, $50.0 \%$ of the coal consumed comes from imports from countries such as the USA, South Africa, Australia and Canada, that is, recurring expenses of the need in development.

On the other hand, the political issue is taking up again. The need to import products from countries like those mentioned above creates extreme interdependence. However, Brazil as an underdeveloped 
country, inserts itself in a reality unfavourable to its growth and world development. The use of easily accessible materials, available in Brazil, such as biomass and the possibility of wind and hydraulic power plants, allows for stability, since international crises will affect Brazil's domestic policy in a more sublime manner. For example, the "Petroleum Shocks", mentioned above, reached several world poles, creating crises at extremities, as interdependent economies tend to create a network of collaborations. The domestic economy depends on the external. Thus, having an internal economic guarantee in energy production brings stability to the entire population.

In other words, the way of obtaining electric energy does not only translate quantity, shape or quality, but it is interleaved between several socioeconomic aspects, starting from the big international branches to houses all over the world. Therefore, the path used for this achievement singles out the model that a country decides to develop.

In contrast to the points already analysed, Brazil has great generating capacity for sustainable and renewable development, but the initiative remains unfavourable, considered unfeasible for administrative and economic reasons. However, decisions that include a viable future in their planning should not be priced. For example, the "National Energy Plan 2030", made by the Ministry of Mines and Energy (MME), in partnership with the Energy Research Company (EPE), has as planning the implementation of a new technique described as "Thermoelectric Generation from of biomass ", where the chemically stored energy in the biomass is transformed into thermal energy through combustion (BRAZIL, 2007).

Biomass as a renewable source in the generation of energy is already part of the Brazilian electric matrix, including $8.2 \%$ in Table 1 , more than the double used worldwide, but it still symbolizes only a complementary source, which concretely results in less waste production harmful. It turns out that Brazil has always had a good agricultural layer in its entire perimeter. In addition to good climatic and territorial quality, rural labour has always been available, even with the various exodus processes. However, the country continues to use a more polluting fuel that needs to be imported as a source of thermal energy (BRAZIL, 2007). Nevertheless, for the implementation of an action plan like this, investments of an economic and scientific nature would be of extreme importance, in addition to the determination to change an energy matrix that would bring a global differential, since as previously mentioned in Table 1 , only $2.3 \%$ worldwide equals the use of biomass.

However, projects like this should resort to a good structure, so that in the future there are no new flaws to be corrected. Therefore, with a long-term sustainability objective, goals that can be made quickly and efficiently should be the starting point in the present. As long as the processes of obtaining energy generate environmental impacts, daily plans must be transformed in search of improvement.

One way to mobilize awareness in the present is in the management of waste from burning coal in thermoelectric plants, which is deposited in areas close to the place of manufacture, and often ends up useless (SANTOS et al., 2015). As previously mentioned, Engie Brasil Energia distributes its ashes to cement industries, which already reduces environmental impacts, makes less waste possible and even makes concrete more resistant. 
The use of ash from coal in the cement industry, figure 4, began in 1947 in the United States, and the following year an experimental track was built to study this application. In 1956, pozzolanic cement with about 12 to $20 \%$ ashes appeared, (SILVA et al., 1980). In Brazil, the use of fly ash began in the 1960s in the construction of the Jupiá Hydroelectric Power Plant. The first pozzolanic cement produced in the country was in 1969 by Cimensul, using ash from the Charqueadas thermoelectric. The coal ash can also be used in the construction of structural embankments, such as stabilized bases and modified and stabilized soils for roads, tracks and buildings, offering after compacted with energy and moisture content defined, a resistant base (ABREU, 1993).

Research carried out by the Energy and Nuclear Research Institute, in partnership with Companhia Carbonífera de Cambuí Ltda, focusing on the Thermoelectric Power Plant at Figueira - PR, observed that the ashes coming from the system can be synthesized and cover other functions. According to the researchers, the ashes are basically formed by silica and alumina, which can be converted into zeolite, a compound that allows several commercial applications (FUNGARO et al., 2006).

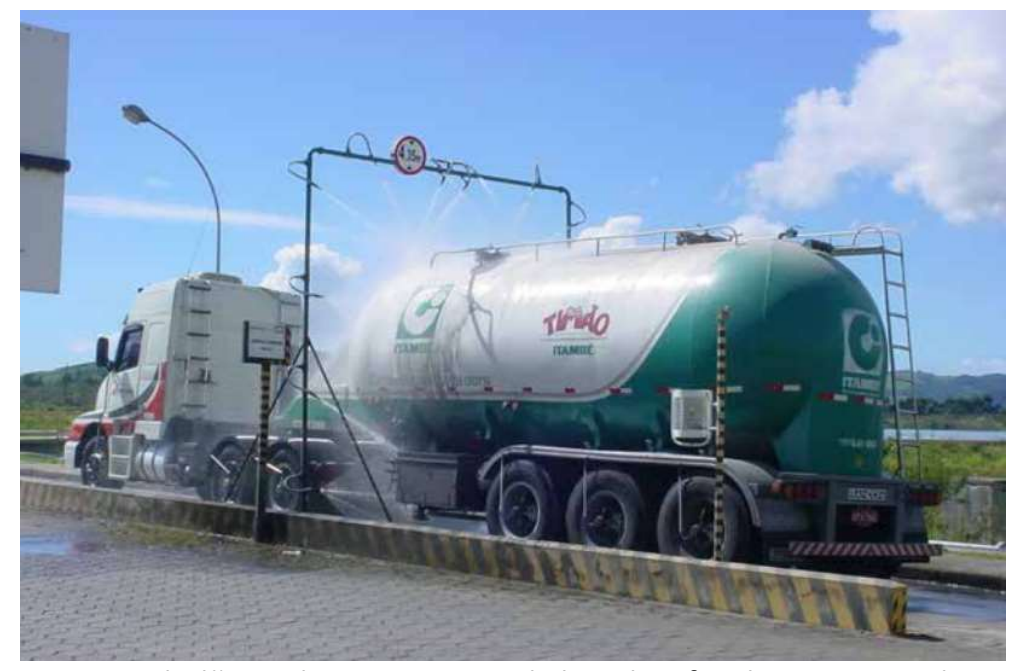

Figure 4: Cebolão trailer transporting light ashes for the cement industry.

Besides the use by cement industries, zeolite has been analysed in other situations that may make trade viable, as in the acid mine drainage treatment, reducing from 70 to $90 \%$ the metallic ions; in the soil remediation of the plant itself that was contaminated with zinc, reducing by $80 \%$ the leaching; treatment of effluents for the disposal in a legally correct way, as in galvanization companies, and even effluents contaminated with dye, being that zeolite managed to retain about $90 \%$ of the methylene blue in aqueous environment without altering the pH (FUNGARO; IZIDORO; ANDRADE, 2006). Studies conducted by the Federal University of Pará, show that it is possible to replace up to $40 \%$ of pozzolanic ash in relation to the content of cement for mortar, maintaining the mechanical characteristics stabelicides in NBR 7215 and NBR 12653 (SIQUEIRA et al., 2012)

Thus, the big issue in the use of energy from the burning of fossil fuels is still the environmental impact it can have. The possibilities for innovate concepts of this process are numerous, where only a few are present in this article. The main point is to establish that it is possible, just obtain an organization capable of systematizing ideas that will have future reflections and will not be just another daydream. Insurgent 
capitalism continues to walk blindfolded towards a future without security or concretions, an uncertain destiny that will be merely a reflection of current reality. Today" modifies "tomorrow", and widening one's gaze to the less obvious is what awakens desire to chart new paths.

The philosopher Herbert Spencer, brought a concept of Darwin, a great evolutionist theorist, to social issues, calling it "Social Darwinism", where certain societies tend to prevail due to a better capacity for adaptation. As an example, the goal of producing quality energy is achieved by any population, but only a few are able to do so without depredation of environments, fauna and flora. As in a natural selection, societies that depredate the environment in which they live, depredate themselves.

\section{CONCLUSIONS}

After visiting the Jorge Lacerda Complex, on Capivari De Baixo, SC, in collaboration with the research carried out throughout the year, it is essential to use renewable energies, since today natural resources grow in arithmetic progression and the population in geometric progression, according to Thomas Malthus, resulting in their fast output and deterioration of the environment.

With the constant technological discoveries, the 21st century has been a time that has enabled an improvement in the quality of life, in addition to new ways of obtaining energy. Such forms can be sustainable or not, but human greed, in many situations, is directed to the last option, therefore, in addition to harming nature, it harms itself. Thermoelectric energy, although not totally clean, is a less polluting option - compared to other non-renewable ones - and contains technologies that reduce environmental impacts, an example is the reuse of water and filters at the top of the chimneys, which reduce the emission of pollutants.

Thus, this article sought to cohesively structure the production of thermoelectric energy, to make it clear how the process occurs and how it impacts the social environment. On the other hand, the article also wanted to highlight, mainly, the discovery of new possibilities. Information is capable of transforming realities, and it is through research like this that the future is transformed, with the dissemination of information.

All energy comes from a single source: nature. For this reason, all the care is necessary to have a reconciliation between the use and the preservation. The awareness of environmental problems - such as global warming and deforestation - must always be reinforced so that, with the support of its inhabitants, each country changes its energy matrix to a sustainable model, thus contributing to a more ecological world.

ACKNOWLEDGEMENT: To the Congregation of the Little Sisters of the Immaculate Conception-CIIC; to the maintainer of the Santa Paulina Education Network, College São José School Unit, city of Itajaí (SC), in people: Director, Sr. Leodi Bolzan, Vice-Director, Mr. Altair Claro, Pedagogical Coordinator, Ms. Nedriane Scaratti Moreira, of all teachers, in particular Maria Cristina Biaggio and Maycon Fritzen, who participated in the evaluation panel of the scientific initiation project, one of the structuring axes of the pedagogical proposal of the Rede Santa Paulina and of all the relatives of the authors responsible for the development of this project that culminated in the publication of this study. 


\section{REFERENCES}

ABREU, I. B.. Characterization of flying spaces of Brazilian carbon-based thermoelectric plants. Use in civil engineering and its environmental implications. Thesis (Doctorate) Universidad Polytechnic de Catalunya, Barcelona, 1993.

ABNT. Brazilian Association of Technical Standards. NBR 7215, Portland Cement: Determination of Compression Strength. Rio de Janeiro: ABNT, 1996.

ABNT. Brazilian Association of Technical Standards. NBR 12653, Pozzolanic Materials: Specification. Rio de Janeiro: ABNT, 1992.

BIOFUELS. The pollution caused by oil and its consequences for the marine environment. Campina Grande: BIOFUELS, 2015.

BRAZIL. Ministry of Mines and Energy. Secretariat for Planning and Energy Development. National Energy Plan 2030: Thermoelectric Generation - Biomass. 8 ed. Brasilia: Eletrobrás, 2007.

CORREIA, F. N.; BEZERRA, I. S.. Pollution caused by oil and its consequences for the marine environment. In: NATIONAL CONGRESS ON PETROLEUM ENGINEERING, NATURAL GAS AND BIOFUELS, 1. Annals. 2015.
DRUMM, F. C.; GERHARDT, A. E.; FERNANDES, G. D. A.; CHAGAS, P.; SUCOLOTTI, M. S.; KEMERICH, P. D. C.. Air pollution from the burning of petroleum-based fuels in motor vehicles. Electronic Journal on Environmental Management, Education and Technology, v.18, n.1, p.66-78, 2014. DOI: http://dx.doi.org/10.5902/2236117010537

FUNGARO, D. A.; IZIDORO, J. C.; ANDRADE, A. O.. Sustainable Development and the Use of Waste from Thermoelectric Plants. São Paulo: Energy and Nuclear Research Institute, 2006.

SANTOS, M. R.; TEIXEIRA, C. E.; KNIESS, C. T.. Environmental eco-efficiency of thermoelectric companies: a proposal for how to measure. In: International meeting on business management and the environment. Annals. São Paulo: Engema, 2015. p.0-16.

SILVA, M. A. M.; CERATTI, J. A. P.. Study of the use of fly ash in blocks for civil construction. Porto Alegre: UFRGS, 1980.

SIQUEIRA, J. D.; SOUZA, C. A. G.; SOUZA, J. A. S.. Reuse of coal ash in the formulation of mortars. Ceramics, v.58, n.346, p.275-279, 2012.

A CBPC - Companhia Brasileira de Produção Científica (CNPJ: 11.221.422/0001-03) detém os direitos materiais desta publicação. Os direitos referem-se à publicação do trabalho em qualquer parte do mundo, incluindo os direitos às renovações, expansões e disseminações da contribuição, bem como outros direitos subsidiários. Todos os trabalhos publicados eletronicamente poderão posteriormente ser publicados em coletâneas impressas sob coordenação da Sustenere Publishing, da Companhia Brasileira de Produção Científica e seus parceiros autorizados. Os (as) autores (as) preservam os direitos autorais, mas não têm permissão para a publicação da contribuição em outro meio, impresso ou digital, em português ou em tradução. 